\title{
DIVERSITY AND PREDATION POTENTIAL OF MAJOR APHIDOPHAGOUS PREDATORS IN MAIZE
}

\author{
SWAMINATHAN, R. ${ }^{*}$ - MEENA, A. - MEENA, B. M. \\ Department of Entomology, Rajasthan College of Agriculture, Maharana Pratap University of \\ Agriculture and Technology, Udaipur-313001, Rajasthan, INDIA \\ * Corresponding author \\ e-mail: udaiswami57@gmail.com; udaiswamirussia@yahoo.co.uk \\ (Received $6^{\text {th }}$ Sep 2014; accepted $23^{\text {rd }}$ Mar 2015; corrected online $23^{\text {rd }}$ May 2016)
}

\begin{abstract}
Investigation on, "Diversity and predation potential of major aphidophagous predators in maize" was carried out at the Instructional Farm, Rajasthan College of Agriculture, Udaipur during summer (April to July, 2013) and monsoon (July to October, 2013) seasons with the objectives to study the diversity of aphids feeding natural enemies and evaluate the predation potential of major insect groups of the aphidophagous guild in the field and laboratory. The aphid pest recorded on maize was Rhopalosiphum maidis (Fitch). Among the aphidophagous predatory guild, the major insect groups included coccinellids (Coccinella septempunctata Linnaeus, Cheilomenes sexmaculatus (Fabricius) and Brumoides suturalis (Fabricius): Coccinellidae, Coleoptera); lygaeid bug (Geocoris sp.: Lygaeidae, Hemiptera,); rove beetle [Paederus fuscipes Curtis: Staphylindae, Coleoptera] and syrphid flies (Ischiodon sp.: Syrphidae, Diptera; being dominant). The seasonal mean population of aphids was higher during monsoon season crop (369.09/plant) than during the summer season (291.26/plant). Likewise, the seasonal mean population of the aphidophagous predators per plant was relatively more during monsoon season being 8.56 (coccinellids), 3.76 (Geocoris sp.), 3.14 ( $P$. fuscipes) and 2.41 (syrphid flies); whereas, in summer season the corresponding values were 7.78 (coccinellids), 3.60 (Geocoris sp.), 2.87 (P. fuscipes) and 1.89 (syrphid flies). Exclusion of the ground dwelling aphidophagous predators resulted into significantly more aphid predation $(99.75 \%)$ than when aerial aphidophagous predators were excluded from access to aphid prey $(89.38 \%)$. In the no exclusion treatment, where both types of predators (aerial and ground dwelling) had equal access to aphid prey, the decrease in aphid numbers was the maximum (100\%). The coccinellid grubs and adult beetles consumed relatively more aphids at lower aphid densities (25, 50 and 75), significantly being the maximum at a prey density of 75 . At higher aphid densities (100, 125 and 150) the consumption rates declined. The feeding behaviour of coccinellids showed a sharp decline in percentage feeding with an increase in prey density for both adults and grubs.
\end{abstract}

Key words: maize aphid, aerial, ground dwelling aphidophagous predators

\section{Introduction}

Agro-ecosystems under intensive agriculture often present unfavourable environments for natural enemies due to high levels of anthropological disturbance, particularly through intensive agriculture. Habitat management that aims at utilizing practices to favour natural enemies, especially, predators and parasitoids towards achieving conservation biological control has been often advocated. A higher natural enemy abundance (Östman et al., 2001) or diversity (Snyder et al., 2006) may not often lead to improved biological control, because prey other than the pest species may be preferred. The corn leaf aphid, Rhopalosiphum maidis (Fitch) is one of the important pests of maize with worldwide distribution (Carena and Glogoza, 2004; Plewa and Pankanin-Franczyk, 1989). It was observed that infestation from 10-leaf stage to tasseling caused 28.14 per cent yield losses (average aphid density 818 aphids/plant); while, infestation 
through ripening stages caused 16.28 per cent yield losses (average aphid density 1038 aphids per plant). Yield losses of corn due to aphid infestation from 10-leaf stage to ripening stage were 14.66, 22.9, 35.28 and 36.03 per cent at average aphid densities of 100, 1000, 2000 and 3000 aphids per plant. This clearly indicates that plant lice, i.e. aphids can cause considerable losses to the crop and thus must be managed through eco-safe methods (Al-Eryan and ElTabbakh, 2004).

The management of sap sucking insect pests through bio-intensive methods renders it important to record the diversity of natural enemies of aphids, both generalist and specific, commonly occurring in any crop ecosystem to exploit them in favour. The aphidophagous arthropod guild can be divided broadly into specialists that include Braconidae and Aphidiinae parasitoids; predatory coccinellids, lacewings and hoverflies (Müller and Godfray, 1999) or generalists that include euryphagous predators like ground beetles and spiders (Lang, 2003). Intra-guild competition is often reported among aphidophagous natural enemies due to their foraging activity when they frequently encounter hetero-specific aphid predators, which may disrupt biological control efforts against aphids where more than one predator species is present; hence, this necessitates carefully choosing a combination of predators for success in biological control of aphids (Hindayana et al., 2001). The present investigation thus envisages working out the diversity of aphidophagous arthropod natural enemies in maize cultivated during summer and in the monsoon season, and their predation potential.

\section{Materials and Methods}

\section{a) Experimental site}

The experimental site was located at the Instructional Farm, Rajasthan College of Agriculture, Udaipur, situated at $75.4^{0} \mathrm{E}$ Latitude and $23.4^{0} \mathrm{~N}$ Longitude at an elevation of 582.17 MSL in the sub-humid southern region of Rajasthan, India. The zone has a typical sub-tropical climatic condition characterized by moderate winter and hot summer associated with high humidity especially during months of August and September. The average rainfall of this tract ranges between $450-650 \mathrm{~mm}$, contributed by South-West monsoon from July to September with occasional rains during the winter season. During summers, the atmospheric temperature may go as high as $45.5^{\circ} \mathrm{C}$, while in winters, it may fall as low as $3.5^{\circ} \mathrm{C}$ occasionally.

\section{b) Field preparation and sowing of maize crop}

One deep ploughing and two cross harrowing were done to improve the field condition. Sowing of summer crop was done on $3^{\text {th }}$ April, 2013 and maintained with timely irrigations; while that of the monsoon crop on $9^{\text {th }}$ August, 2013 and was cultivated rainfed. Phosphatic fertilizer was applied as basal dose of $40 \mathrm{~kg} / \mathrm{ha}$, while $\mathrm{N}$ was applied at $80 \mathrm{~kg} / \mathrm{ha}$ in two split doses. The other agronomic practices such as thinning, hoeing and weeding were performed as and when needed following the package of practices for cultivation of maize.

\section{c) Natural enemy collections}

The aphidophagous predators were collected along with their aphid prey from maize (Variety: Pratap makka) fields during summer and monsoon seasons in 
2013. Collections were made twice a week during the aphid infestation period beginning at tassel initiation stage. The aphidophagous natural enemy diversity was also recorded and collected from the same maize fields.

\section{d) Arthropod monitoring}

a) Pest aphids count

The population count was made from 5 randomly-selected maize plants from each replicate of the 4 treatments (mentioned later), selecting the top $20 \mathrm{~cm}$ meristematic region where aphids usually congregate and feed. The number of winged and wingless adults, nymphs and mummies (mummified aphids hosting parasitoids) for each aphid species was accounted for during observation.

b) Aphidophagous natural enemy count

i. Parasitoid count

The aphid parasitoids were estimated from the count of aphid mummies per plant as per methodology mentioned above.

ii. Specific and generalist predator count

The predator abundance was recorded as per stage of development:

a) First, larvae of lacewings, coccinellids and hoverflies were counted on the same shoots used to count the aphids.

b) Second, adult aerial predators, mainly coccinellids, were recorded visually by walking in between the central rows of maize in each replicate and expressing the population on a per plant basis from the top $20 \mathrm{~cm}$ shoot.

c) Third, the ground-dwelling predators were collected using pitfall traps. Three pitfall traps ( $\mathrm{ca} 500 \mathrm{ml}$ glass jar with ethylene glycol) were positioned diagonally within each replicate. The traps were dug down to ground level. Transparent plastic covers were placed above the traps to prevent flooding by rain during the monsoon season.

d) Aphids and aerial predator transects were inspected between 7:00 and 8:00 a. $\mathrm{m}$.

e) Ambient atmospheric temperature $\left({ }^{\circ} \mathrm{C}\right)$ and relative humidity $(\%)$ was measured prior to sampling. Sampling was carried out as soon as aphid infestation began.

f) The aphidophagous predator community was determined to species, wherever possible, in addition, the predators were classified into specific or generalist predators.

\section{e) Efficacy of aphidophagous natural enemy guild}

A field cage experiment to test the effect of aphidophagous predator guild on aphid population was carried out at the Instructional Agronomy Farm, RCA Udaipur on summer and monsoon season maize. In each selected field the following treatments were taken that were replicated 6 times: 
(1) An open control (O)

(2) Ground-dwelling predator exclusion (G)

(3) Aerial predator and parasitoid exclusion (F) and

(4) Total exclusion (T), which was the combination of treatments (Asin and Pons, 1998) and (Carena and Glogoza, 2004), i.e., G and F.

Metallic barriers to exclude ground-dwelling predators (e.g., spiders, carabids, staphylinids) were placed. The barriers were circular, $0.5 \mathrm{~m}$ in diameter, dug into the soil. Ground-dwelling predators captured in these traps were counted and removed. Aerial aphid predators and parasitoids were excluded by setting wire cages over the plants. The cages were of a mesh size of $8 \mathrm{~mm}$ allowing airflow to avoid changes in microclimate conditions (Schmidt et al., 2003) and were covered with sticky glue to intercept or hinder aerial predators and parasitoids from entering. The bottom edge of the cages was left without glue to permit ground-dwelling predators access. With a view to maintain a uniform initial population, at initiation of tassel in the summer crop of maize, aphid abundance was recorded on $20 \mathrm{~cm}$ length of top shoot and 1-day before caging, ca 500 aphids were left on the shoot removing excess aphids, wherever present, with the help of a camel hair brush.

\section{Culture of coccinellids in the laboratory and predation potential trial}

a) The adult coccinellids were field collected from the untreated crop fields of the Instructional Farm of the College and brought to the laboratory to maintain a stock culture under ambient conditions of temperature and humidity. The mean atmospheric temperature ranged from 23 to $34^{\circ} \mathrm{C}$ and at 51 to 74 per cent relative humidity. Mating pairs were kept in glass jars (500ml capacity) covered with muslin cloth that was fastened with rubber bands. The eggs laid on maize leaves (Soares et al., 2003) were placed into fresh glass jars till the first instar grubs emergence, which were then provisioned with fresh maize aphids daily as food.

b) To evaluate the predation potential of coccinellid grubs at different aphid densities $(25$, $50,75,100,125$ and 150), four healthy second instar grubs were separated with the help of a camel hair brush after the first moult and transferred into individual glass jars of $500 \mathrm{ml}$ capacity covered with a muslin cloth held together by rubber bands, considered as 4 replicates. Observations on the consumption of aphids were recorded in each replicate under the different treatments after $24 \mathrm{~h}$. The experiment was continued for 5 days and left over aphids and dried maize shoots were replaced daily with fresh ones to avoid contamination and consequent mortality.

c) To evaluate the predation potential of adult beetles, Coccinella septempunctata (Linneaus), Cheilomenes sexmaculata (Fabricius) and the colour morph of $\mathrm{Ch}$. sexmaculata were field collected from the untreated maize crop and reared on the maize aphid (dominant being $R$. maidis) as prey. Having starved the adult coccinellids for $6 \mathrm{~h}$ they were individually transferred to glass jars with different aphid prey densities on fresh maize leaves replicated 4 times. Observations on consumption of aphids were recorded in each replicate under the different 
treatments after $24 \mathrm{~h}$. The evaluation was continued for 5 days replacing left over aphids and dried maize shoots daily with fresh ones to avoid contamination and consequent mortality.

\section{Mathematical and statistical analyses}

The following mathematical analysis was made towards estimating the species richness of aphidophagous natural enemies and their diversity indices:

Mean density (MD)

$$
\text { Mean density }(\mathrm{MD})=\frac{\mathrm{Xi}}{\mathrm{N}}
$$

Where, $\mathrm{Xi}=$ Numbers of insects; $\mathrm{N}=$ Total numbers of plants sampled.

\section{Relative density (RD)}

$$
\mathrm{RD} \%=\frac{\text { Number of individual of one species }}{\text { Total number of individual of all species }} \times 100
$$

\section{Shannon -Weiner diversity index (H')}

$$
\text { Shannon - Weiner diversity index }\left(H^{\prime}\right)=-\Sigma \text { pi ln pi }
$$

Where, $\mathrm{Pi}=$ the decimal fraction of individuals belonging to ith species

\section{Predation Efficiency}

The predation efficiency of dominant aphidophaous coccinellids was evaluated through the determination of the voracity following the model of Soares et al. (2003):

$$
\mathrm{Vo}=(\mathrm{A}-\mathrm{a} 24) \text { ra } 24
$$

Where, $\mathrm{Vo}=$ number of aphids eaten; $\mathrm{A}=$ number of aphids available a 24 = number of aphids alive after $24 \mathrm{~h}$ and ra $24=$ ratio of aphids found alive after $24 \mathrm{~h}$ in the absence of predators.

The data obtained were subjected to Analysis of Variance and other suitable statistical procedures to analyze the results of the investigations conducted. 


\section{Results}

\section{Aphid incidence and the diversity of their natural enemies}

The aphids collected from maize were Rhopalosiphum maidis (Fitch) [Aphididae: Hemiptera]. The associated natural enemies of aphids on maize included coccinellids [Coccinella septempunctata Linneaus, Cheilomenes sexmaculata (Fabricius) and Brumoides suturalis (Fabricius), Coccinellidae: Coleoptera]; the big-eyed bug [Geocoris sp., Lygaeidae: Hemiptera]; the rove beetle [Paederus fuscipes Curtis, Staphylinidae: Coleoptera]; and syrphid flies [major being Ischiodon sp., Syrphidae: Diptera].

The seasonal incidence of the maize aphid during the summer and monsoon seasons, as presented in Tables 1 and 2 respectively, indicate that the seasonal mean aphid abundance on maize during monsoon was relatively more than that during summer season. The mean population ranged from 237.00 aphids per plant to 373.05 aphids per plant with the seasonal mean being 291.26 aphids per plant on the summer crop (Table 1).

Table 1. Population dynamics of maize aphid and its natural enemies during summer, 2013

\begin{tabular}{|c|c|c|c|c|c|c|c|}
\hline \multirow{2}{*}{ Dates of observation } & \multirow{2}{*}{$\begin{array}{l}\text { Mean Atm. } \\
\text { Temp. }\left({ }^{\circ} \mathrm{C}\right)\end{array}$} & \multirow{2}{*}{$\begin{array}{c}\text { Mean } \\
\text { R. H. (\%) }\end{array}$} & \multicolumn{5}{|c|}{ Mean Population per Plant } \\
\hline & & & Aphids & Coccinellids & Geocoris sp. & Rove beetles & Syrphids \\
\hline $20-05-2013$ & 34.50 & 24.50 & 271.01 & 5.43 & 3.55 & 2.98 & 1.69 \\
\hline $23-05-2013$ & 34.65 & 14.95 & 272.85 & 5.51 & 3.48 & 2.91 & 1.71 \\
\hline $26-05-2013$ & 33.10 & 34.00 & 274.54 & 5.70 & 3.39 & 2.86 & 1.78 \\
\hline $29-05-2013$ & 33.35 & 37.00 & 276.06 & 6.28 & 3.60 & 3.03 & 1.82 \\
\hline $01-06-2013$ & 32.15 & 42.50 & 275.28 & 6.91 & 3.42 & 2.88 & 1.79 \\
\hline 04-06-2013 & 32.70 & 57.00 & 278.85 & 7.69 & 3.53 & 2.84 & 1.84 \\
\hline $07-06-2013$ & 30.10 & 59.50 & 300.34 & 7.65 & 3.66 & 3.09 & 1.86 \\
\hline $10-06-2013$ & 31.10 & 54.50 & 345.62 & 9.16 & 3.68 & 3.17 & 1.91 \\
\hline $13-06-2013$ & 28.30 & 84.00 & 347.58 & 11.77 & 4.01 & 3.27 & 2.40 \\
\hline $16-06-2013$ & 30.20 & 58.50 & 373.05 & 11.71 & 4.50 & 3.32 & 2.56 \\
\hline $19-06-2013$ & 30.60 & 62.00 & 302.07 & 9.34 & 3.43 & 2.95 & 2.15 \\
\hline $22-06-2013$ & 28.95 & 66.50 & 277.71 & 9.08 & 3.41 & 2.93 & 2.05 \\
\hline $25-06-2013$ & 31.20 & 60.50 & 245.68 & 7.61 & 3.68 & 2.29 & 1.76 \\
\hline $28-06-2013$ & 28.55 & 74.50 & 237.00 & 5.14 & 3.05 & 1.64 & 1.11 \\
\hline Seasonal Mean & 31.39 & 52.14 & 291.26 & 7.78 & 3.60 & 2.87 & 1.89 \\
\hline \multicolumn{3}{|c|}{ CC:r-values for population and mean atm. temp. } & -0.30 & $-0.61 *$ & -0.16 & 0.17 & -0.25 \\
\hline \multicolumn{3}{|c|}{ CC: r-values for population and mean R .H. } & 0.28 & $0.63^{*}$ & 0.17 & -0.18 & 0.26 \\
\hline \multicolumn{4}{|c|}{ CC: r-values between populations of aphids and natural enemies } & $0.84 *$ & $0.82 *$ & $0.76^{*}$ & $0.84 *$ \\
\hline
\end{tabular}

$\mathrm{CC}=$ Coefficient of correlation; * Values significant at 5\% level; Population data are means of 20 plants (5 plants $\mathrm{x} 4$ replications)

Likewise, the mean population ranged from 269.85 aphids per plant to 520.12 aphids per plant with the seasonal mean being 369.09 aphids per plant on the monsoon season crop (Table 2). During summer season, the mean atmospheric temperature had a mild negative correlation with the aphid population, while the mean relative humidity evinced a mild positive correlation with the aphid population though the r-values were non-significant. During monsoon season, the mean atmospheric temperature had a significant positive correlation with the aphid population $(\mathrm{r}=0.65)$; whereas, the mean relative humidity showed a mild positive influence on aphid population. It could be inferred that an increase in the mean atmospheric temperature during summer caused a reduction in aphid numbers, while during monsoon it caused a significant increase in aphid numbers. 
Table 2. Population dynamics of maize aphid and its natural enemies during monsoon, 2013

\begin{tabular}{|c|c|c|c|c|c|c|c|}
\hline \multirow{2}{*}{ Dates of observation } & \multirow{2}{*}{$\begin{array}{l}\text { Mean Atm. } \\
\text { Temp. }\left({ }^{\circ} \mathrm{C}\right)\end{array}$} & \multirow{2}{*}{$\begin{array}{c}\text { Mean } \\
\text { R. H. (\%) }\end{array}$} & \multicolumn{5}{|c|}{ Mean Population per Plant } \\
\hline & & & Aphids & Coccinellids & Geocoris sp. & Rove beetles & Syrphids \\
\hline $02-09-2013$ & 26.70 & 71.00 & 327.43 & 8.42 & 3.61 & 3.13 & 2.11 \\
\hline $05-09-2013$ & 26.45 & 51.00 & 334.53 & 8.91 & 3.75 & 3.07 & 2.18 \\
\hline $08-09-2013$ & 26.85 & 61.00 & 403.02 & 9.56 & 3.70 & 3.23 & 2.28 \\
\hline $11-09-2013$ & 28.75 & 68.50 & 425.75 & 9.46 & 3.83 & 3.09 & 2.35 \\
\hline $14-09-2013$ & 28.00 & 62.50 & 502.12 & 10.58 & 4.83 & 4.45 & 3.23 \\
\hline $17-09-2013$ & 29.80 & 79.50 & 520.12 & 10.41 & 4.70 & 3.66 & 4.07 \\
\hline $20-09-2013$ & 26.50 & 86.00 & 423.69 & 9.70 & 4.03 & 3.05 & 2.67 \\
\hline $23-09-2013$ & 25.25 & 84.00 & 384.75 & 9.10 & 4.15 & 3.13 & 2.35 \\
\hline $26-09-2013$ & 25.25 & 79.50 & 355.63 & 7.85 & 3.71 & 2.97 & 2.26 \\
\hline $29-09-2013$ & 25.90 & 77.00 & 337.43 & 8.23 & 3.53 & 3.00 & 2.18 \\
\hline $02-10-2013$ & 27.95 & 80.50 & 302.42 & 7.43 & 3.29 & 2.84 & 2.16 \\
\hline $05-10-2013$ & 26.75 & 67.00 & 299.95 & 7.23 & 3.32 & 2.86 & 2.05 \\
\hline $08-10-2013$ & 24.85 & 68.50 & 280.63 & 6.61 & 3.22 & 2.74 & 1.96 \\
\hline $11-10-2013$ & 25.90 & 60.00 & 269.85 & 6.40 & 2.96 & 2.72 & 1.91 \\
\hline Seasonal Mean & 26.78 & 71.14 & 369.09 & 8.56 & 3.76 & 3.14 & 2.41 \\
\hline \multicolumn{3}{|c|}{ CC:r-values for population and mean atm. temp. } & $0.65^{*}$ & $0.59 *$ & $0.52^{*}$ & $0.53^{*}$ & $0.70^{*}$ \\
\hline \multicolumn{3}{|c|}{ CC:r-values for population and mean R.H. } & 0.19 & 0.10 & 0.20 & -0.10 & 0.25 \\
\hline \multicolumn{4}{|c|}{ Coefficient of correlation between aphids and natural enemies } & $0.94^{*}$ & $0.95^{*}$ & $0.83^{*}$ & $0.89^{*}$ \\
\hline
\end{tabular}

$\mathrm{CC}=$ Coefficient of correlation; $*$ Values significant at $5 \%$ level; Population data are means of 20 plants (5 plants $\mathrm{x} 4$ replications)

In accordance to the aphid numerical abundance and being density-dependent, the associated aphidophagous natural enemies were relatively a little more during the monsoon season as compared to that during the summer season. The mean adult coccinellid population (inclusive of 4 species) ranged from 5.14 to 11.77 per plant with the seasonal mean of 7.78 beetles per plant on the summer crop; while the corresponding values for monsoon crop were 6.40 to 10.58 per plant with the seasonal mean of 8.56 beetles per plant. The lygaeid bug, Geocoris was in significant numbers with the seasonal mean of 3.60 and 3.76 bugs per plant during summer and monsoon seasons, respectively. The staphylinids had a seasonal mean population of 2.87 and 3.14 per plant, while the syrphids were 1.89 and 2.41 per plant during the summer and monsoon seasons, respectively. It could be observed the populations of the aphidophagous natural enemies were more during monsoon than in summer, possibly being favoured by the humid conditions. The population of coccinellids showed much variation, while that of Geocoris, staphylinids and syrphids did not show much variation within the seasons (Tables 1 and 2). The population trend of the maize aphid and the associated natural enemies has been depicted in the Figures 1 and 2, based on log population of both during summer and monsoon seasons, respectively.

Among the aphidophagous natural enemy guild recorded during both the summer and monsoon seasons, coccinellids dominated with 48.23 and 47.91 per cent relative density, respectively; followed by the big-eyed bug, Geocoris with a RD value of 22.30 and 21.03 per cent (Table 3). However, the Shanon diversity index values did not differ for the two seasons (1.25 and 1.24 for summer and monsoon, respectively). 


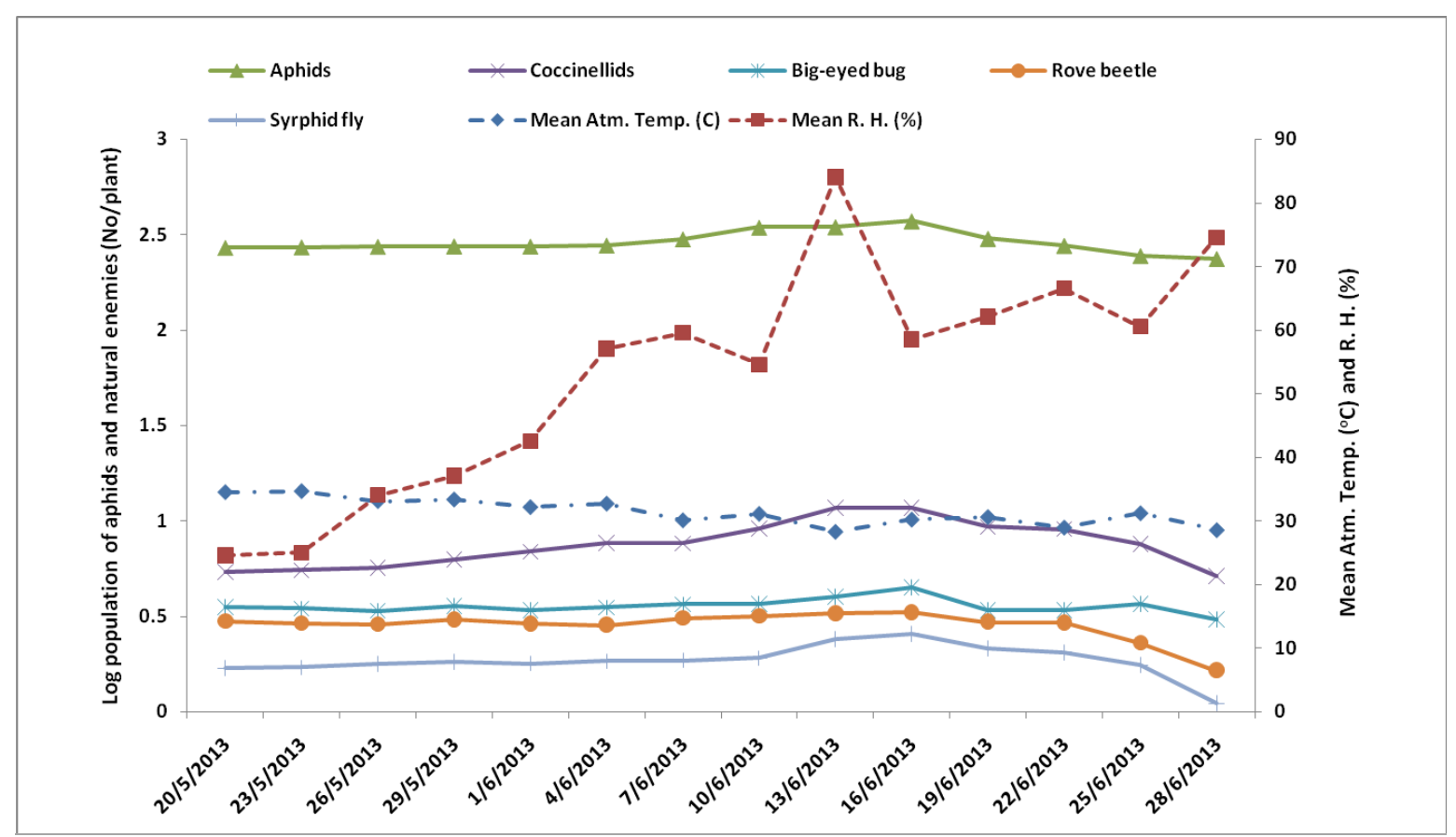

Figure 1. Population trend of maize aphids and associated natural enemies during summer, 2013

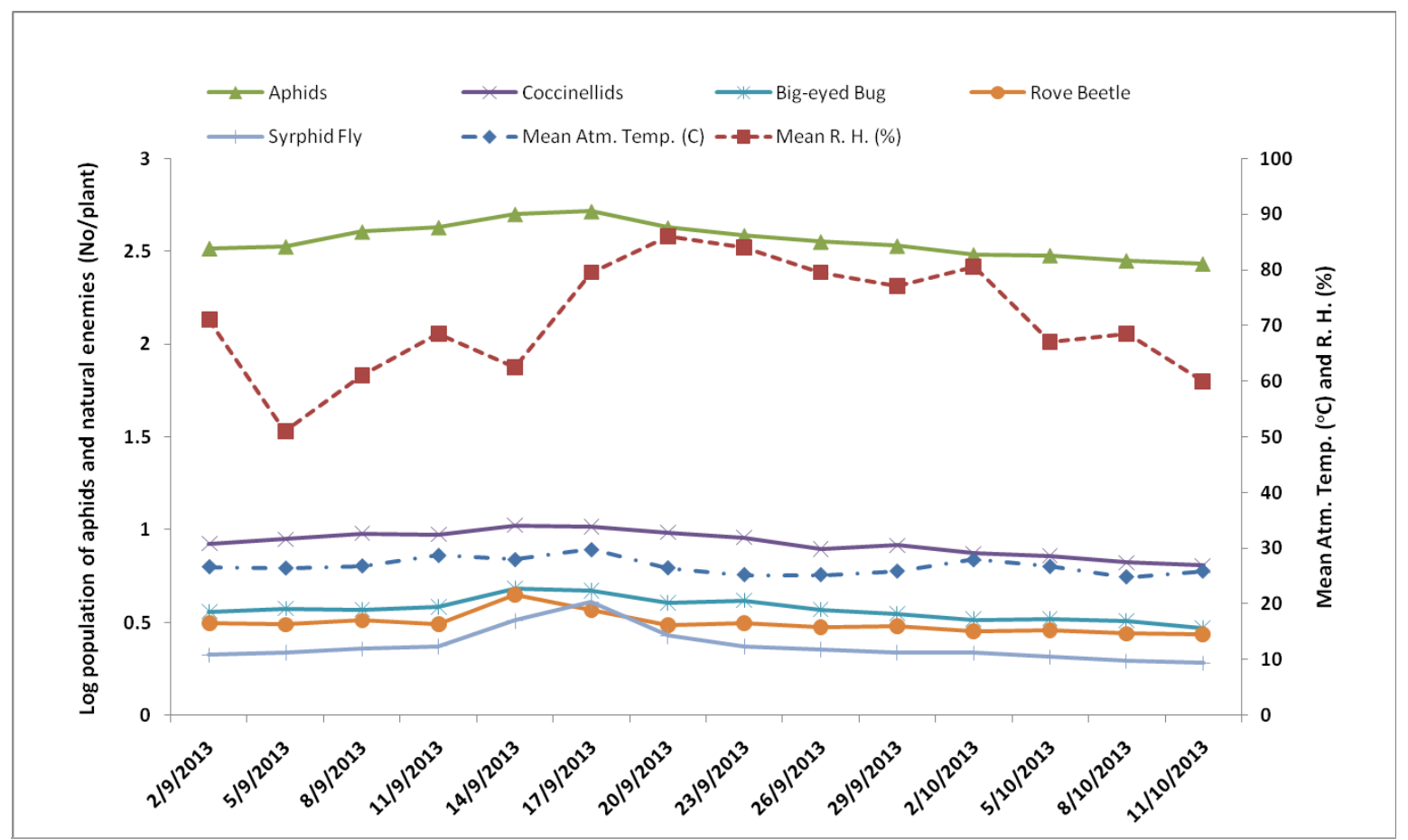

Figure 2. Population trend of maize aphids and associated natural enemies during monsoon, 2013

APPLIED ECOLOGY AND ENVIRONMENTAL RESEARCH 13(4): 1069-1084. 
Table 3. Dominant predators of maize aphid during two seasons in 2013

\begin{tabular}{|c|c|c|c|c|}
\hline \multirow{2}{*}{$\begin{array}{c}\text { Aphidophagous } \\
\text { predators }\end{array}$} & \multicolumn{2}{|c|}{ Summer Crop } & \multicolumn{2}{|c|}{ Monsoon Crop } \\
\hline & $\begin{array}{l}\text { Seasonal } \\
\text { Mean* }\end{array}$ & $\begin{array}{c}\text { Relative } \\
\text { Density (\%) }\end{array}$ & $\begin{array}{l}\text { Seasonal } \\
\text { Mean* }\end{array}$ & $\begin{array}{c}\text { Relative } \\
\text { Density }(\%)\end{array}$ \\
\hline Coccinellids & 7.78 & 48.23 & 8.56 & 47.91 \\
\hline Geocoris spp. & 3.60 & 22.30 & 3.76 & 21.03 \\
\hline Rove beetles & 2.87 & 17.77 & 3.14 & 17.56 \\
\hline Syrphid fly & 1.89 & 11.70 & 2.41 & 13.49 \\
\hline Shanon D I & \multicolumn{2}{|c|}{1.24} & \multicolumn{2}{|c|}{1.25} \\
\hline
\end{tabular}

* Seasonal mean population expressed as numbers per plant

\section{Efficacy of the aphidophagous guild}

The efficacy of the aphidophagous guild was evaluated in a field experiment wherein known numbers of aphids were caged or excluded from predation by aerial predators, ground dwelling predators, both and an uncaged or open control. It was notable that excluding aerial predators enabled ground dwelling predators to access the aphids, while exclusion of ground dwelling predators enabled the aerial predators to access the apids. Likewise, exclusion of both types of predators resulted in exponential population growth of the aphids. From the Table 4 and Figure 3 it becomes clear that aerial predators contributed significantly more towards aphid predation than the ground dwelling predators, as shown by the decrease in aphid numbers from 500 to 4.17 at five days after treatment; whereas, ground dwelling predators caused a decrease in aphid numbers from 500 to 56.67 at five day after treatment. However, in the no exclusion treatment, where access to aphid prey was provided to both types of predators (aerial and ground dwelling) the decrease in aphid numbers was the maximum being 3.00 at four days after treatment and zero at five days after treatment. It is therefore conspicuous that the aphidophagous predators play a major role in maintaining the aphid populations below those causing economic damage. Nevertheless, one can observe these predators actively foraging except on rainy days while in the field. 
Table 4. Prey consumption by aphidophagous predator-guild in different exclusion treatments

\begin{tabular}{|c|c|c|c|c|c|c|c|}
\hline \multirow{2}{*}{$\begin{array}{l}\text { Exclusion Treatment for } \\
\text { Aphidophagous Predators }\end{array}$} & \multirow{2}{*}{$\begin{array}{l}\text { PTP of } \\
\text { Aphids } \\
\text { (No./plant) }\end{array}$} & \multicolumn{5}{|c|}{ Left-over Aphid Population (No:s/plant) } & \multirow{2}{*}{$\begin{array}{l}\text { Consequent Prey } \\
\text { Consumption by }\end{array}$} \\
\hline & & 1-DAT & 2-DAT & 3-DAT & 4-DAT & 5-DAT & \\
\hline Aerial & 500 & 406.67 & 331.67 & 240.00 & 136.67 & 56.67 & $\begin{array}{l}\text { Ground dwelling } \\
\text { predators }\end{array}$ \\
\hline Ground dwelling & 500 & 283.33 & 137.50 & 55.00 & 21.67 & 4.17 & Aerial predators \\
\hline $\begin{array}{l}\text { Both aerial and ground dwelling } \\
\text { (Total Exclusion) }\end{array}$ & 500 & $\begin{array}{l}670.00 \\
(34.00)\end{array}$ & $\begin{array}{l}820.83 \\
(47.89)\end{array}$ & $\begin{array}{l}936.67 \\
(53.20)\end{array}$ & $\begin{array}{l}1055.00 \\
(59.25)\end{array}$ & $\begin{array}{r}1163.33 \\
(62.87)\end{array}$ & No predators \\
\hline Control (No exclusion) & 500 & 154.17 & 48.33 & 12.83 & 3.00 & 0.00 & $\begin{array}{l}\text { Both aerial and ground } \\
\text { dwelling predators }\end{array}$ \\
\hline S.Em. \pm & -- & 30.27 & 33.54 & 35.69 & 40.50 & 37.11 & \\
\hline C.D. $(5 \%)$ & -- & 91.22 & 101.08 & 107.54 & 122.03 & 111.82 & \\
\hline
\end{tabular}

Note: Population count of aphids per plant on $20 \mathrm{~cm}$ top shoot in each treatment; DAT = Days after Treatment

Values in parentheses indicate the cumulative percent increase in aphid population in the total exclusion treatment

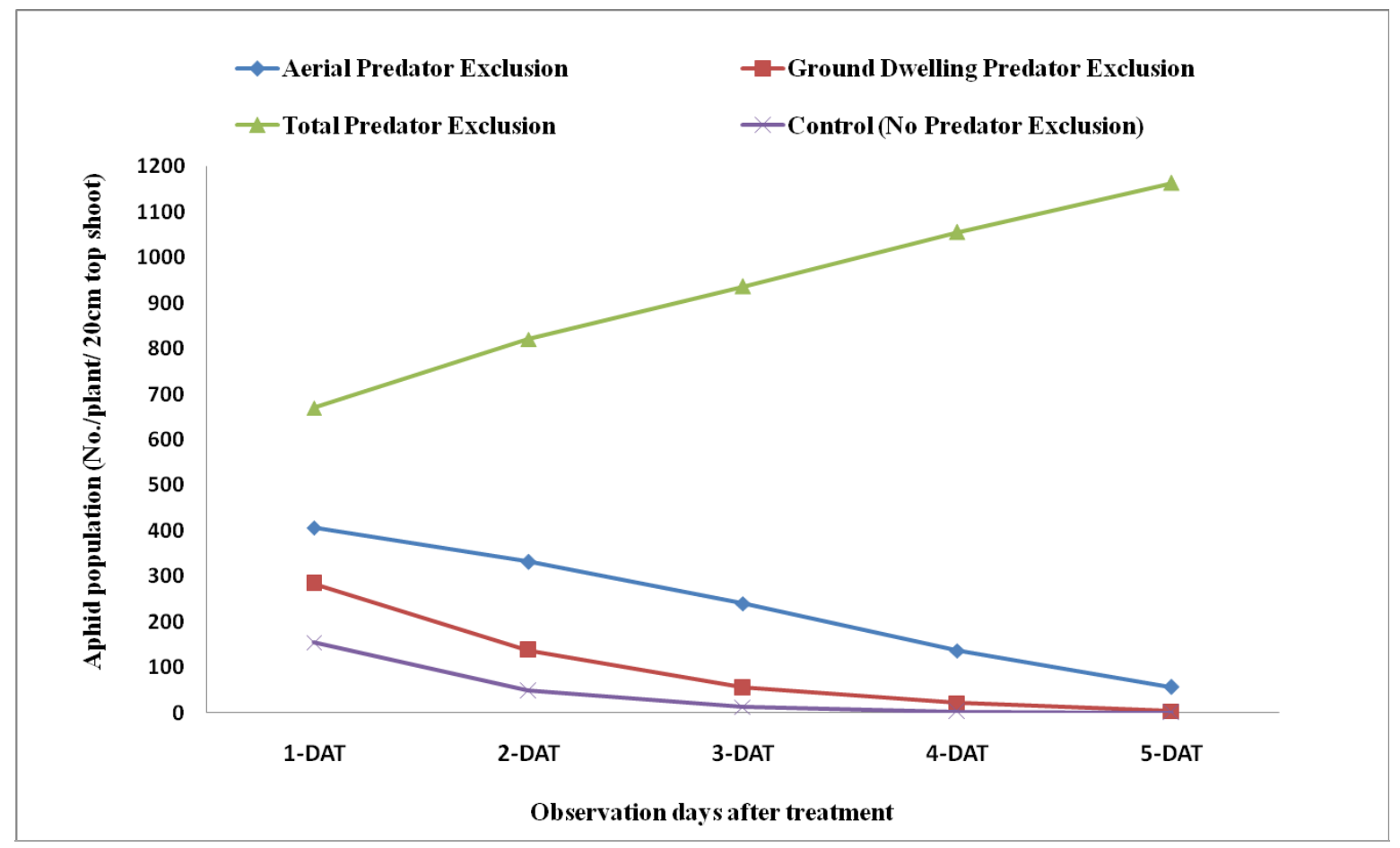

Figure 3. Influence of aphidophagous predator exclusion treatments on prey population

A perusal of the Table 5 explains the feeding propensity of these aphidophagous predators under different exclusion treatments. Aphid consumption (\%) was maximum (100 per cent) under no exclusion treatment (control) closely followed by when ground dwelling predators were excluded $(99.75 \%)$; whereas, it was 89.38 per cent when aerial predators 
were excluded. The treatment of total exclusion (excluding both aerial and ground dwelling predators), in contrast, showed a cumulative increase in the aphid population over the initial population of 500 aphids per plant depicting an increase from 34.00 to 62.87 per cent (Table 4) (Fig. 3).

Table 5. Feeding propensity of aphidophagous predators under different exclusion treatments

\begin{tabular}{|c|c|c|c|c|c|c|}
\hline \multirow{2}{*}{$\begin{array}{l}\text { Exclusion Treatment for } \\
\text { Aphidophagous Predators }\end{array}$} & \multicolumn{5}{|c|}{ Aphid Consumption (\%) } & \multirow{2}{*}{$\begin{array}{l}\text { Consequent Prey } \\
\text { Consumption by }\end{array}$} \\
\hline & 1-DAT & 2-DAT & 3-DAT & 4-DAT & 5-DAT & \\
\hline Aerial & $\begin{array}{l}25.37^{\mathrm{a}} \\
(18.36)\end{array}$ & $\begin{array}{l}35.27^{\mathrm{a}} \\
(33.34)\end{array}$ & $\begin{array}{l}46.18^{\mathrm{a}} \\
(52.05)\end{array}$ & $\begin{array}{l}58.99^{\mathrm{a}} \\
(73.46)\end{array}$ & $\begin{array}{r}70.98^{\mathrm{a}} \\
(89.38)\end{array}$ & $\begin{array}{l}\text { Ground dwelling } \\
\text { predators }\end{array}$ \\
\hline Ground dwelling & $\begin{array}{l}41.00^{\mathrm{b}} \\
(43.04)\end{array}$ & $\begin{array}{l}58.93^{b} \\
(73.36)\end{array}$ & $\begin{array}{l}71.87^{b} \\
(90.31)\end{array}$ & $\begin{array}{l}80.31^{\mathrm{b}} \\
(97.17)\end{array}$ & $\begin{array}{l}87.12^{b} \\
(99.75)\end{array}$ & Aerial predators \\
\hline Control (No exclusion) & $\begin{array}{l}56.42^{\circ} \\
(69.41)\end{array}$ & $\begin{array}{l}72.31^{\circ} \\
(90.76)\end{array}$ & $\begin{array}{l}81.04^{\mathrm{c}} \\
(97.58)\end{array}$ & $\begin{array}{l}86.88^{b} \\
(99.70)\end{array}$ & $\begin{array}{c}90.00^{\mathrm{b}} \\
(100.00)\end{array}$ & $\begin{array}{l}\text { Both aerial and ground } \\
\text { dwelling predators }\end{array}$ \\
\hline S. Em. \pm & 2.68 & 3.03 & 2.30 & 2.84 & 1.43 & \\
\hline C.D. $(5 \%)$ & 8.44 & 9.56 & 7.24 & 8.94 & 4.51 & \\
\hline
\end{tabular}

DAT $=$ Days after Treatment; Figures in parentheses are retransformed percent values; Values with similar letters are statistically at par

\section{Predation potential of the major aphidophagous guild}

The predation potential of the dominant aphidophagous guild comprising the adult and grubs of coccinellids of three species was evaluated by their feeding behavior at different aphid prey densities $(25,50,75,100,125$ and 150 per beetle). From the Table 6 it can be inferred that the grubs of Coccinella septempunctata could feed significantly more aphids at the different densities evaluated followed by Cheilomenes sexmaculata.

Table 6. Feeding behaviour of aphidophagous coccinellid grubs at different prey densities

\begin{tabular}{|c|c|c|c|c|c|c|}
\hline \multirow{2}{*}{$\begin{array}{l}\text { Aphid Prey } \\
\text { Provided } \\
\text { (№:s/ 24h) }\end{array}$} & \multicolumn{2}{|c|}{ Coccinella septempunctata } & \multicolumn{2}{|c|}{ Cheilomenes sexmaculata-1 } & \multicolumn{2}{|c|}{ Cheilomenes sexmaculata-2 } \\
\hline & $\begin{array}{c}\text { Prey } \\
\text { Consumed } \\
\text { (№:s/ 24h) }\end{array}$ & $\begin{array}{c}\text { Feeding } \\
(\%)\end{array}$ & $\begin{array}{c}\text { Prey Consumed } \\
\text { (№:s/24h) }\end{array}$ & $\begin{array}{c}\text { Feeding } \\
(\%)\end{array}$ & $\begin{array}{c}\text { Prey Consumed } \\
\text { (№:s/24h) }\end{array}$ & $\begin{array}{c}\text { Feeding } \\
(\%)\end{array}$ \\
\hline 25 & $20.55^{\mathrm{a}}$ & 82.20 & 19.70 & 78.80 & 19.00 & 76.00 \\
\hline 50 & $22.95^{\mathrm{b}}$ & 45.90 & 21.65 & 43.30 & 20.55 & 41.10 \\
\hline 75 & $24.70^{\mathrm{c}}$ & 32.93 & 23.00 & 30.66 & 21.15 & 28.20 \\
\hline 100 & $22.10^{\mathrm{ab}}$ & 22.10 & 20.75 & 20.75 & 19.80 & 19.80 \\
\hline 125 & $22.30^{\mathrm{ab}}$ & 17.84 & 21.72 & 17.37 & 20.05 & 16.04 \\
\hline 150 & $21.40^{\mathrm{ab}}$ & 14.26 & 20.00 & 13.33 & 18.95 & 12.63 \\
\hline S. Em. \pm & 0.73 & & 0.49 & & 0.34 & \\
\hline C.D. $(5 \%)$ & 2.20 & & 1.47 & & 1.03 & \\
\hline
\end{tabular}

Prey = Maize aphid; values with similar letters are statistically at par. 
The coccinellid grubs increasingly and significantly consumed more aphids at aphid densities of 25, 50 and 75, but at higher aphid densities (100, 125 and 150) the consumption rate declined. The prey consumption on a number basis differed significantly at different densities with $C$. septempunctata feeding 20.55 to 24.70 and $C h$. sexmaculata feeding 19.70 to 23.00 or 18.95 to 21.15 aphids in 24 hours with the maximum being when 75 aphids as prey were provided. From the Figure 4 on feeding behavior it becomes clear that an increase in prey density sharply decreased the per cent feeding by the grubs. Notwithstanding the fact that aphidophagous coccinellids prefer to feed on aphids, they are specific predators of aphids at low densities between 25 and 50. However, this gives an indication that field releases of coccinellid grubs might prove useful at higher aphid densities considering the feeding ability of a single coccinellid grub.

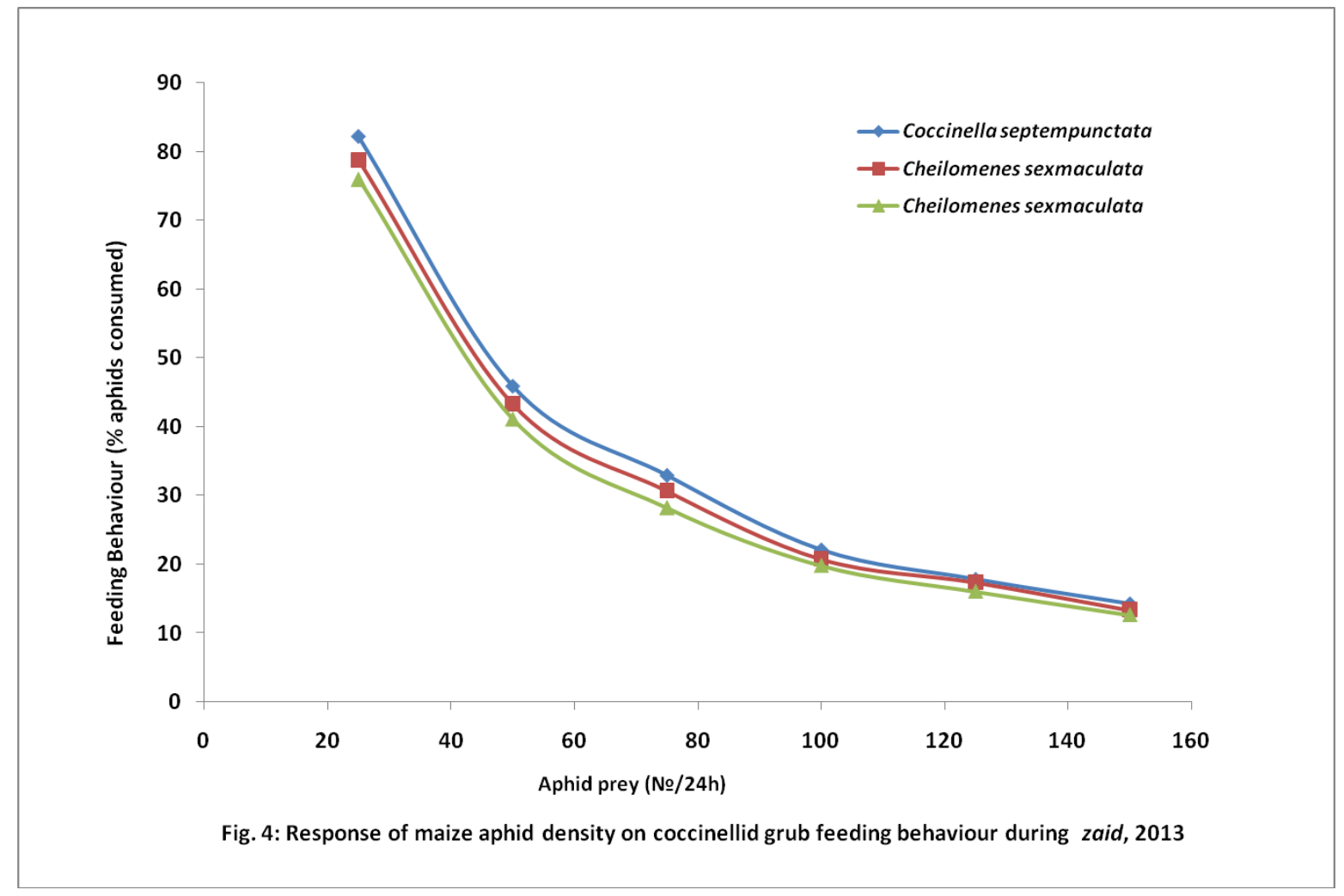

Figure 4. Response of maize aphid density on coccinellid grub feeding behaviour during summer, 2013

A perusal of the Table 7 indicates that the adult coccinellids showed little difference in their feeding potential. Similar to the behavior of grubs, the adult coccinellids consumed more aphids with increase in the prey density up to 75 aphids per adult; thereafter their feeding capacity declined. The prey consumption on a number basis did not differ much at different densities with $C$. septempunctata feeding 18.70 to 22.55 and $C h$. sexmaculata feeding either 17.80 to 20.95 or 15.95 to 19.35 aphids in 24 hours with the maximum being when 75 aphids as prey were provided. Similar to the feeding behavior of grubs, from the 
Figure 5 it can be observed that an increase in prey density sharply decreased the per cent feeding.

Table 7. Feeding behaviour of aphidophagous adult coccinellids at different prey densities

\begin{tabular}{|c|c|c|c|c|c|c|}
\hline \multirow[b]{2}{*}{$\begin{array}{l}\text { Aphid Prey } \\
\text { Provided } \\
\text { (№:s/ 24h) }\end{array}$} & \multicolumn{2}{|c|}{ Coccinella septempunctata } & \multicolumn{2}{|c|}{ Cheilomenes sexmaculata-1 } & \multicolumn{2}{|c|}{ Cheilomenes sexmaculata-2 } \\
\hline & $\begin{array}{c}\text { Prey } \\
\text { Consumed } \\
\text { (№:s/ 24h) }\end{array}$ & $\begin{array}{l}\text { Feeding } \\
(\%)\end{array}$ & $\begin{array}{c}\text { Prey } \\
\text { Consumed } \\
\text { (№:s/ 24h) }\end{array}$ & $\begin{array}{l}\text { Feeding } \\
(\%)\end{array}$ & $\begin{array}{c}\text { Prey } \\
\text { Consumed } \\
\text { (№:s/ 24h) }\end{array}$ & $\begin{array}{l}\text { Feeding } \\
(\%)\end{array}$ \\
\hline 25 & $18.70^{\mathrm{a}}$ & 74.80 & $17.80^{\mathrm{a}}$ & 71.20 & $16.80^{\mathrm{a}}$ & 67.20 \\
\hline 50 & $20.40^{\mathrm{b}}$ & 40.80 & $19.60^{\mathrm{ab}}$ & 39.20 & $17.50^{\mathrm{ab}}$ & 35.00 \\
\hline 75 & $22.55^{\mathrm{c}}$ & 30.06 & $20.95^{\mathrm{c}}$ & 27.93 & $19.35^{\mathrm{b}}$ & 25.80 \\
\hline 100 & $20.10^{\mathrm{b}}$ & 20.10 & $18.95^{\mathrm{a}}$ & 18.95 & $17.20^{\mathrm{a}}$ & 17.20 \\
\hline 125 & $20.20^{b}$ & 16.16 & $19.20^{\mathrm{ab}}$ & 15.36 & $17.35^{\mathrm{ab}}$ & 13.88 \\
\hline 150 & $19.55^{\mathrm{ab}}$ & 13.03 & $17.95^{\mathrm{a}}$ & 11.96 & $15.95^{\mathrm{a}}$ & 10.63 \\
\hline S. Em. \pm & 0.35 & & 0.39 & & 0.46 & \\
\hline C.D. $(5 \%)$ & 1.05 & & 1.18 & & 1.39 & \\
\hline
\end{tabular}

Prey = Maize aphid; values with similar letters are statistically at par

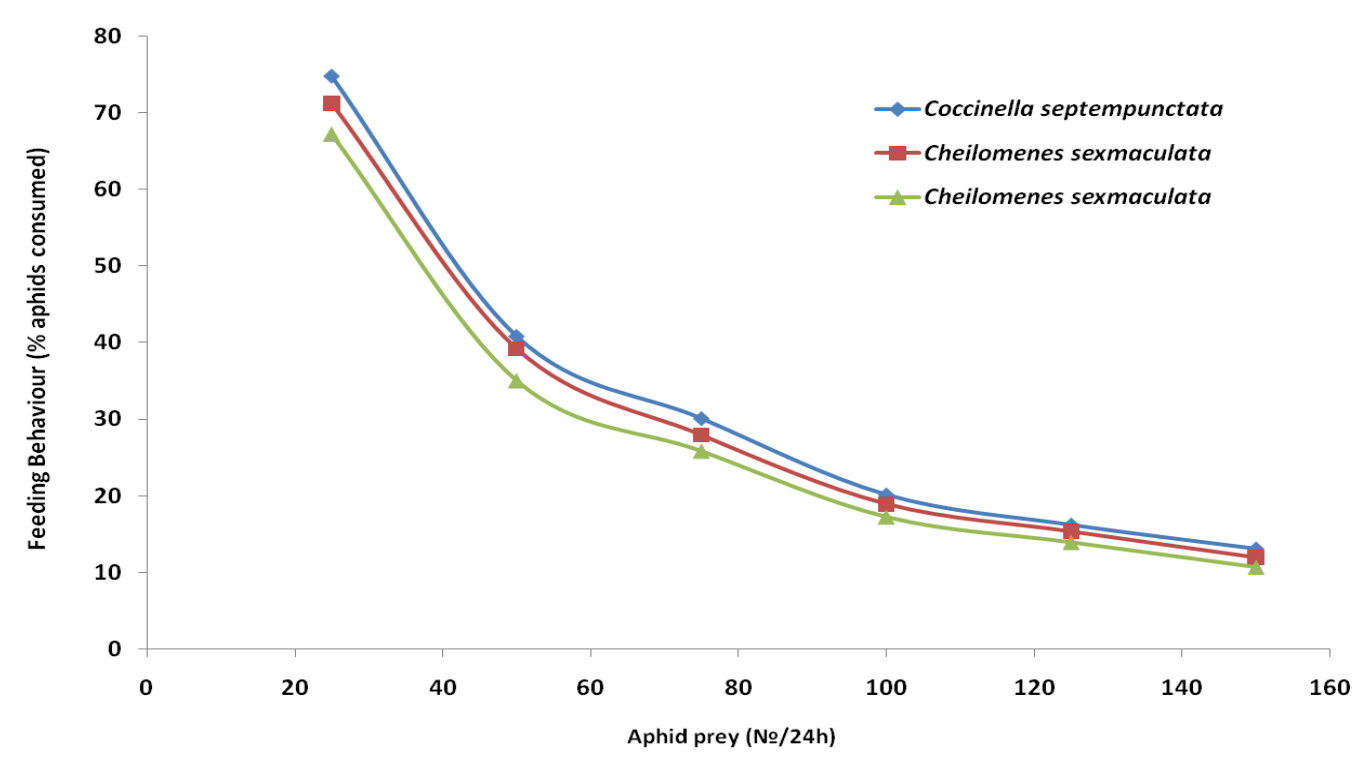

Fig. 5: Response of maize aphid density on adult coccinellid feeding behaviour during kharif, 2013

Figure 5. Response of maize aphid density on adult coccinellid feeding behaviour during monsoon, 2013 


\section{Discussion}

Earlier workers have also reported Rhopalosiphum maidis (Fitch) as the major aphid pest on maize (Razmjou and Golizadeh, 2010) ; however, Rhopalosiphum padi, Sitobion avenae and Metopolophium dirhodum were also recorded in addition (Coderre and Tourneur, 1988; Coderre et al., 1989; Plewa and Pankanin-Franczyk, 1989). During 1988 and 1989, Schizaphis graminum and Rhopalosiphum maidis were reported to infest maize (Darwish and Ali, 2001). The aphid, Rhopalosiphum maidis was recorded on maize from 3 regions of Romania to be controlled by 23 species of predatory insects, including 2 anthocorids, 3 nabids, 2 chrysopids, a cantharid, 2 malachiids, 10 coccinellids and 3 syrphids (Voicu, 1989). Coccinellids (4 species) and chrysopids (3 species) were the most abundant predators, followed by syrphids and nabids, and 6 species of aphidiid [Braconidae] parasitoids (Plewa and Pankanin-Franczyk, 1989). Among aphid predators, the coccinellids, Coleomegilla maculata lengi and Hippodamia tredecimpunctata were significantly more abundant in the monoculture than in the maize intercropped with beans, but Coccinella septempunctata and spiders were not (Coderre et al., 1989). Though coccinellids (Coccinella septempunctata, Adonia variegata, Propylaea quatuordecimpunctata) were the most common aphid-specific predators, polyphagous predators were more abundant, mainly anthocorids (Orius spp.), carabids (Demetrias atricapillus, Harpalus rufipes, Bembidion spp., Poecilus cupreus, Agonum dorsale), dermapterans (Labidura riparia, Forficula auricularia), nabids (Nabis provencalis) and spiders (Asin and Pons, 1998). The relatively more common aphidophagous predators on maize belonged to the insect families Chrysopidae, Coccinellidae, Nabidae and Syrphidae; types of soil, forerunner crops and fertilizers affected the dynamics of the aphid-predator system in Romania (Paulian, 1999). Similar to our observation, among coccinellids, $C$. septempunctata, $C$. transversalis, Brumoides suturalis and Cheilomenes sexmaculata are the most widespread (Singh and Brar, 2004). Thus, it can be inferred that coccinellids happen to be the most dominant aphidophagous predators of maize aphids as recorded during the present investigation.

The aphid, Rhopalosiphum (two species) showed a bimodal seasonal distribution, with a decrease in abundance at the end of July. Climatic factors and emigration could not explain this decrease, but was probably related to diminished plant nutritional quality and an increase in predation (Coderre and Tourneur, 1988). Aphids occurred at the beginning of August, and reached their maximum abundance (406 and 518 per plant) in the $4^{\text {th }}$ week of August, when the plants were in their reproductive stage. Aphid populations began to decrease from the $3^{\text {rd }}$ week of September, to reach their lowest levels in mid-October, when the plants were mature (Darwish and Ali, 2001).

The mean daily consumption of the aphid, $R$. maidis by adults and larvae of $C$. septempunctata to be 30.4 and 27.7 at $18.6^{\circ} \mathrm{C}$ and 71 per cent relative humidity that increased with an increase in the daily temperature (Harjit and Deol, 1999). Contrary to our findings that coccinellids were more efficient at lower aphid densities, earlier it was reported that the number of attacks by coccinellid adults increased significantly and linearly with increasing prey density. Adult consumption rates were 82-85 per cent in 1997 and 7697 per cent in 1998. Larvae consumption also increased significantly and linearly with prey density and the consumption rates were 80-93 per cent in 1997 and 85-94 per cent in 1998 
(Dicko, 2000). Adults of $C$. septempunctata consumed a significantly higher number of aphids than larvae of Syrphus sp., but less than adults of $M$. sexmaculata. Adults consumed a significantly higher number of maize aphids than immature stages. Grubs of $C$. septempunctata were more active than maggots of Syrphus (Singh and Marwaha, 2002).

Acknowledgements. The authors thank Dr. V.V. Ramamurthy, Principal Scientist and National Coordinator, ICAR Network Project on Insect Biosystematics for the funds, and the Director Research, Maharana Pratap University of Agriculture and Technology for making available the necessary facilities to conduct the investigation.

Change history: The online version of this paper was modified on $23^{\text {rd }}$ May 2016. The coccinellid beetle Illeis cincta (Fabricius) has been misidentified, it is in fact Cheilomenes sexmaculata (Fabricius), a possible colour morph without the wavy markings on elytra. Hence data presented for Illeis cincta (Fabricius) should be considered as those of the coccinellid beetle, Cheilomenes sexmaculata (Fabricius) only, and interpreted accordingly.

\section{REFERENCES}

[1] Al-Eryan, M. A. S., El-Tabbakh, S. S. (2004): Forecasting yield of corn, Zea mays infested with corn leaf aphid, Rhopalosiphum maidis. - Journal of Applied Entomology 128: 312-315.

[2] Asin, L., Pons, X. (1998): Aphid predators in maize fields. - Bulletin OILB/SROP 21: 163170.

[3] Carena, M. J., Glogoza, P. (2004): Resistance of corn to the corn leaf aphid: a review Maydica 49: 241-254.

[4] Coderre, D., Tourneur, J. C. (1988): Summer decline in aphid populations on maize. - Revue d'Entomologie du Quebec 33: 16-24.

[5] Coderre, D., Provencher, L., Champagne, J. (1989): Effect of intercropping maize-beans on aphids and aphidophagous insects in corn fields of southern Quebec, Canada. - Acta Phytopathologica et Entomologica Hungarica 24: 59-63.

[6] Darwish, Y. A., Ali, A. M. (2001): Field population trends of cereal aphids and their natural enemies on corn plants in Upper Egypt. - Assiut Journal of Agricultural Sciences 22:33-42.

[7] Dicko, I. O. (2000): Predation by Cheilomenes propinqua on corn leaf aphid. - International Sorghum and Millets Newsletter 41: 43-47.

[8] Harjit, K., Deol, G.S. (1999): Population build-up and comparative biology of corn leaf aphid, Rhopalosiphum maidis (Fitch) on wheat and barley. - Journal of Insect Science 12: 41-45.

[9] Hindayana, D., Meyhofer, R., Scholz, D., Poehling, H. (2001): Intraguild predation among the hoverfly, Episyrphus balteatus de Geer (Diptera: Syrphidae) and other aphidophagous predators. - Biological Control 20: 236 - 246.

[10] Lang, A. (2003): Intraguild interference and biocontrol effects of generalist predators in a winter wheat field. - Oecologia 134: 144-153.

[11] Müller, C. B., Godfray, H. C. J. (1999): Predators and mutualists influence the exclusion of aphid species from natural communities. - Oecologia 119: 120-125.

[12] Östman, Ö., Ekbom, B., Bengtsson, J. (2001): Landscape heterogeneity and farming practice influence biological control. - Basic and Applied Ecology 2: 365-371.

[13] Paulian, M. (1999): Green lacewings (Neuroptera Chrysopidae) in the aphid-predator system on maize in mild temperate climate. - Bollettino dell'Istituto di Entomologia 'Guido Grandi' della Universita degli Studi di Bologna 53:39-48. 
[14] Plewa, T., Pankanin-Franczyk, M. (1989): Aphids and aphidophages on maize in central Poland. - Acta Phytopathologica et Entomologica Hungarica 24: 169-171.

[15] Razmjou, J,. Golizadeh, A. (2010): Performance of corn leaf Aphid, Rhopalosiphum maidis (Fitch) (Homoptera:Aphididae) on selected maize hybrids under laboratory conditions. Applied Entomology and Zoology 45:267-274.

[16] Schmidt, M. H., Lauer, A., Purtauf, T., Thies, C., Schaefer, M., Tscharntke, T. (2003): Relative importance of predators and parasitoids for cereal aphid control. - Proceedings of the Royal Society of London Series B, Biological Sciences 70: 1905-1909.

[17] Singh, M. R., Marwaha, K. K. (2002): Feeding potential of some effective predators against maize aphid, Rhopalosiphum maidis (Fitch). - Shashpa 9: 89-91.

[18] Singh, J., Brar, K. S. (2004): Mass production and biological control potential of coccinellids in India. - In: Sahayaraj, K. (Ed) Indian Insect Predators in Biological Control, Daya Publishing House, New Delhi, 204-260pp.

[19] Snyder, W. E., Snyder, G. B., Finke, D. L., Straub, C. S. (2006): Predator biodiversity strengthens herbivore suppression. - Ecology Letters 9: 789-796.

[20] Soares, A. O., Coderre, D., Schanderl, H. (2003): Effect of tempera- ture and intraspecific allometry on predation by two pheno- types of Harmonia axyridis Pallas (Coleoptera: Coccinellidae). - Environmental Entomology 32: 939-944.

[21] Voicu, M. C. (1989): The role of the predatory insects in reducing the attack of the corn grain aphid (Rhopalosiphum maidis Fitch) (Hom., Aphididae) in Romania. - Revue Roumaine de Biologie 34: 95-105. 